\title{
Planning and Design of Surface Drainage System of an Agricultural Farmland using HCS Curve Number Method with Most Economical Section
}

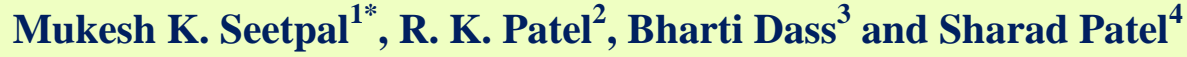 \\ ${ }^{1}$ School of Agriculture, ITM University, Gwalior, Madhya Pradesh, India \\ ${ }^{2}$ Department of Soil and Water Engineering, College of Agricultural Engineering, \\ Jawaharlal Nehru Krishi Vishwa Vidyalaya, Jabalpur, India \\ ${ }^{3}$ Instrument Development and Service Centre, College of Agricultural Engineering, \\ Jawaharlal Nehru Krishi Vishwa Vidyalaya, Jabalpur, India \\ ${ }^{4}$ National Institute of Hydrology, Roorkee, Uttarakhand, India
}

*Corresponding author

\section{A B S T R A C T}

\begin{tabular}{l} 
Ke y w o r d s \\
Drainage, Drainage \\
coefficient, \\
Antecedent \\
Moisture Condition, \\
Curve number \\
method, Land use \\
land cover \\
Article Info \\
Accepted: \\
10 April 2020 \\
Available Online: \\
10 May 2020 \\
\hline
\end{tabular}

\section{Introduction}

Water is the main element in the production and growth of crop. Appropriate quantity of water is necessary for plant growth, when quantity of water is less than requirement of plant, plant get stressed and yield of crop lowered down. When quantity of water is more than requirement of crop, then also plant get stressed and yield of crop lowered down. 
When water applied to crop is less than its requirement than we apply water to crop and overcome this situation but when quantity of water in field is more than its requirement then its removal is necessary. Removal of this excess water from agricultural field is known as agricultural drainage. Drainage means the process of removing water from soil that is in excess of the need of crop plants or drainage is the removal of excess gravitational water from the soil by artificial means to enhance crop production. Removal of this excess water is done through mainly either by providing adequate surface drainage system or by subsurface drainage system.

Excess water in the crop root zone soil is injurious to plant growth. Crop yields are drastically reduced on poorly drained soils, and in cases of prolonged water logging, plants eventually die due to a lack of oxygen in the root zone. Sources of excess soil water that result in high water tables include: high precipitation in humid regions; surplus irrigation water and canal seepage in the irrigated lands; and artesian pressure. Water logging in irrigated regions may result in excess soil salinity, i.e., the accumulation of salts in the plant root zone.

According to country report of Central Water Commision January 2009 in India total waterlogged area is about 1719.279 thousand hectare and in MP it is about 0.543 thousand hectare. Artificial drainage is essential on poorly drained agricultural fields to provide optimum air and salt environments in the root zone.

Drainage is regarded as an important water management practice, and as a component of efficient crop production systems. World food supply and the productivity of existing agricultural lands can only be maintained and enhanced if drainage improvements are undertaken on cropland currently affected by excess water and high water tables. Jharia P.,(2013) designed an economic drainage system for farm of JNKVV campus. She divides whole study area into two part; one is paddy area and other is non-paddy area.

The drainage coefficient for 5 year return period was found as $0.559 \mathrm{~cm} /$ day for paddy area and $1.019 \mathrm{~cm} /$ day for non-paddy area by using Curve Number method and Cyprus Creek formula. An attempt was made to propose a set of drainage sections computed based on the drainage coefficient arrived and that presently did not implemented in the study area. Fourteen different fields' drains sections and one sub main and one main drain sections were proposed for the study area.

Dabral P. P. et al., (2007), estimated the drainage coefficient for North Lakhimpur (Assam). From 24 years daily rainfall data (1981-2004), year wise one to seven consecutive days maximum rainfall was obtained. Three commonly used distribution functions (viz .normal, $\log$ normal and Gamma) were fitted. From the best fitted functions one to seven consecutive days rainfall values for 2, 5, 10 and 20 years recurrence interval (R. I.) was determined.

The drainage coefficients were calculated subtracting basic infiltration rate from consecutive days maximum rainfall for R.I. of 2,5,10 and 20 years. Study reveals that the soil of North Lakhimpur (Assam) having predominantly loamy to clay loam soils and infiltration rate between 1 to $5 \mathrm{~mm} / \mathrm{hr}$ may necessarily have to be provided with agricultural land drainage for its major crops grown in the area.

Luo, W. et al., (2008) study shows that the YinNan Irrigation District in NingXia, China diverts each year about 1.6 - $109 \mathrm{~m} 3$ water from the Yellow River for irrigation use. More than half of that water is discharged 
back to the downstream channel or some lowlying depressions as a result of agricultural drainage. Several studies have indicated that the District is excessively drained, partially caused by the over-dimensioning of the existing drainage system, and proposed to improve the situation by controlled drainage practice.

They subsequently carried out a field experiment of controlled drainage in the rice growing area of the District in 2004-2005. Field observations showed that reduction of the drainage depth of field ditches from 1 to $0.4 \mathrm{~m}$ resulted in a drainage flow reduction of $50-60 \%$.

Welderufael et al., (2009) found that in Ethiopia vertisols cover is about $10 \%$ of the total land area and is the fourth most important soil used for crop production, accounting for nearly $23 \%$ of the total arable land used for crop production. More than half of the vertisols are found in the Central Highlands of Ethiopia, with an altitude of more than $1500 \mathrm{~m}$ above mean sea level.

The unique physical and chemical properties of these soils and the high rainfall during the main cropping season create severe surface waterlogging problems which hinder crop production activities. Severe surface waterlogging affects the growth of plants by impeding nutrient uptake and creating oxygen deficiency around the root zone. To address this crop production problem, three surface water drainage methods, namely broad bed and furrow (BBF), ditch, and flat (traditional) methods were evaluated using the water balance of the plant root zone and wheat as a test crop.

R. K. Panda et al., (2003) designed an economic drainage system for coastal paddy areas of Orissa. The drainage coefficient for 5 year return period was found as $100 \mathrm{~mm}$ /day.
An attempt was made to propose a set of drainage sections computed based on the drainage coefficient arrived at by adopting the water budget model and that presently adapted in the Mahanadi delta area. Five different fields drains sections and two collector drain sections were proposed for the study area.

Shekhawat, R. S., (2007). Economic Analysis of Sub-Surface Drainage (SSD) under Indira Gandhi Nahar Pariyojna Command Area has been done and the study has shown that waterlogging adversely affects crop yields. The cost on SSD installation in the command area comes out to be Rs 23767 per hectare. The returns on crop yields before and after the drainage system have been compared. Land utilization has been intensified after the installation of drainage, as a sizeable area of formerly fallow land has been brought under cultivation. The benefit cost ratio $(\mathrm{B}: \mathrm{C})$ and the net present value (NPV) have been found as 2.44 and Rs 34275/ha, respectively. The internal rate of return (IRR) has been found to be 25.88 per cent. These indicators have well established the financial feasibility of the project in the IGNP area.

Rao (1985) has done work on the design of surface drainage for low land rain fed rice crop area which needed information regarding the most critical season and the amounts of rain water to be removed. Fifty years rainfall data were analyzed for probable monthly rainfall, expected dates of different cumulative rainfalls, rainfall depth-durationfrequency data and probable continuous dry spells. This analysis help in identifying the season of heaviest rains and the expected dates by which the peak transplanting operations would begin in that area. As both of these periods are likely to occur at the same time, the most critical season for the drainage in that region is identified as the month of July. 


\section{Study area}

The problematic area is situated behind the Biotechnology Centre in Jawahar lal Nehru Krishi Vishwavidyalaya, Jabalpur which lies between North latitude $23^{\circ} 12^{\prime} 41.33^{\prime \prime}$ and $23^{\circ} 13^{\prime} 19.85^{\prime \prime}$ and East longitude $79^{\circ} 57^{\prime} 52.44^{\prime \prime}$ and $79^{\circ} 58^{\prime} 20.88^{\prime \prime}$ at an altitude of $395.43 \mathrm{~m}$ above msl as shown in figure 1 . The problematic area is about 75.50 ha and consists of various land use i.e. cropland is about 73 ha, tree land 2 ha and Open area (Pasture) - 0.5ha. The area comes under hot sub-humid climate. The average annual rainfall is $1354.4 \mathrm{~mm}$ and most of the rainfall received from south west (S-W) monsoon which generally outbreaks on the second week of June. July, August and September are the three principle months of precipitation and the weather remains almost dry in the remaining months.

In the rainy season, the area becomes waterlogged and the excess water cannot be drained due to lack of proper drainage as shown in figure 2 . and also due to poor conditions of drainage lines available there as shown in figure 3.

\section{Materials and Methods}

\section{Analysis of rainfall data}

The ten years data analyzed shows that there is much variation in the annual rainfall. The minimum annual rainfall recorded as low as $1038 \mathrm{~mm}$ whereas the maximum value is $2684.7 \mathrm{~mm}$. the average annual rainfall is computed as $1552.21 \mathrm{~mm}$. rainfall data from 2005 to 2014 were analyzed to find out maximum one, two, three, four and five consecutive days rainfall at different recurrence interval. In order to estimate drainage coefficient for surface drainage, 24 hours rainfall is required (USDA Manual) at five years recurrence interval, 24 hours rainfall for the study area is $230 \mathrm{~mm}$ which is calculated by using figure 4 .

\section{Soil characteristic of the problematic area}

Soil characteristics which are important for drainage investigations have been determined for the study area. Infiltration characteristics of the soil have been determined at three different locations (tree area, crop area and tree +crop area) and soil samples for textural analysis were collected from three different locations.

\section{Textural classification of the soil}

Soil samples collected from the field of different vegetal cover i.e. tree area, crop area, tree plus crop area and open field comes under the problematic area. Samples were analyzed by mechanical analysis method. Analysis shows that the clay contain of the soil ranges from 29.3 to 29.8 percent, silt 31.1 to 33.5 percent and sand 37.2 to 39.1 percent and hence soils of the study area are classified as clay loam soils.

\section{Infiltration characteristics of the soil}

The standard double cylinder infiltrometer was used to determine the infiltration rate of the soil. The tests were conducted at three locations in the study area. The mean constant infiltration rate of the soil of the problematic area is determined as $0.55 \mathrm{~cm} / \mathrm{hr}$.

\section{Contour map and 3-D surface map of study area}

On taking elevation of $30 \mathrm{~m} \times 30 \mathrm{~m}$ grid of study area minimum elevation was found $389.5 \mathrm{~m}$ and maximum elevation was $397 \mathrm{~m}$. Readings of elevations were put on Surfer 9.0 that created contour map (figure 5) and 3-D surface map (figure 6) of study area. On analyzing 3-D surface map of study area, it 
was found that various places were impounded of water due to which water logging conditions were created, that lowers down the yield of paddy in that area, therefore this map helps in identifying the location with heavy water logging and further helps in taking remedial action.

\section{Drainage plan}

In study area there is no any problem related with high water table so area does not need any sub surface drainage system. Water logging creates problem in only rainy season, in rabi season conditions are normal. The design of a surface drainage system first involves the quantification of the excess water to be drained and the rate at which it has to be drained (drainage coefficient) to avoid the ill effects of surface water logging on the crops and on the soil. Secondly, the design involves calculating the drainage channel geometry and the surface drainage network layout. Thus the design of surface drainage consists of two stages. The first stage is referred as the hydrological design for estimating or establishing the design drainage coefficient and the second stage is referred as the hydraulic design for facilitating the drainage.

\section{Hydrologic design}

The hydrologic soil cover complex method (CN method) considers several watershed parameters according to the selected Ia versus $\mathrm{S}$ relations. These are Antecedent Moisture Condition (AMC), hydrologic soil group (based on infiltration characteristics), land use and land cover.

\section{Antecedent moisture condition (AMC)}

It is a measure of how wet or dry a watershed is when rainfall occurs for which the runoff is to be estimated. AMC was calculated as the sum of the previous five days rainfall prior to the rainfall under consideration for estimation of runoff. Based on the previous five days rainfall total (>53 $\mathrm{mm}$ ), the problematic area comes under the class AMC III.

\section{Hydrologic soil group}

Based on infiltrability, soils are classified into four hydrologic soil groups A, B, C and D. The infiltration rate of the soil is low (2.5 $12.5 \mathrm{~mm} / \mathrm{h}$ ) hence the soil of problematic area comes under the hydrologic soil Group C.

Relation between Ia and $\mathrm{S}$ for the above condition is given as Ia $=0.1 \mathrm{~S}$.

\section{Land use and cover}

The total study area was 75.5 ha which had cropped land about 73.5 ha under straight cultivation and the cover condition was good, forestry land about 2.0 ha in poor coverage and Open area (Pasture) about 0.54 ha, coverage was less than 50 per cent hence it was considered as poor coverage.

\section{Curve number}

The curve number which is a quantitative value for a watershed $(0<\mathrm{CN}<100)$, was decided based on the previously described properties. Assigning a Curve Number to the watershed is an attempt to quantify the runoff producing capability of the watershed from several qualitative and some quantitative parameters for using the number of runoff estimation for a known rainfall.

Weighted Curve number for non-paddy area $=$ $578.46 / 6.5=89.00$

Total paddy area is about 68.5 ha and it is excluded from the weighted average $\mathrm{CN}$ computation due to its special requirement of standing water, bunded condition and saturated soil condition during its growth 
period. A standard $\mathrm{CN}$ of 95 is assumed for paddy lands due to its saturated soil condition (high runoff potential) and this is used to estimate runoff after making an initial deduction $(50 \mathrm{~mm})$ from the rainfall to account for the storage requirement.

\section{Determination of drainage coefficient}

Drainage coefficient and the designed discharge have been calculated by Cypras Creek formula. The problematic area consists of mainly two parts i.e. non-paddy area and paddy area. Hence the drainage coefficients for both the areas were calculated.

\section{Drainage coefficient for non-Paddy area}

Curve Number for non-paddy area is 89.00

Estimated 6-h rain $=0.6 \times 230=138 \mathrm{~mm}$.

$$
\begin{aligned}
\mathrm{S} & =\{(1000 / \mathrm{CN})-10\} \times 25.4 \mathrm{~mm} \\
& =\{(1000 / 89.00)-10\} \times 25.4 \\
& =31.4 \mathrm{~mm} .
\end{aligned}
$$

24-h rainfall at 5-years recurrence interval $\mathrm{P}=$ $230 \mathrm{~mm}$

$$
\begin{aligned}
& \mathrm{Y}=(\mathrm{P}-0.1 \mathrm{~S})^{2} /(\mathrm{P}+0.9 \mathrm{~S}) \\
& \quad=\{138-(0.1)(31.4)\} 2 /\{138+(0.9) \\
& (31.4)\} \\
& \quad=109.4 \mathrm{~mm} . \\
& \mathrm{C}=0.2098+0.0074 \mathrm{Y} \\
& \quad=0.2098+0.0074(61.80) \\
& \quad=1.019
\end{aligned}
$$

\section{Drainage coefficient for paddy area}

Curve Number for paddy area is 95 .

Allow $50 \mathrm{~mm}$ retention in bunded paddy fields.

Balance $=109.4-50=59.4 \mathrm{~mm}$

$\mathrm{S}=\{(1000 / 95)-10\} \times 25.4$

$$
=13.4 \mathrm{~mm} \text {. }
$$

$$
\begin{aligned}
& \mathrm{Y}=\{59.4-(0.1)(13.4)\} \quad 2 / \quad\{59.4 \quad+ \\
& \begin{array}{l}
(0.9)(13.4)\} \\
=47.2 \mathrm{~mm} . \\
\mathrm{C}=0.2098+0.0074 \mathrm{Y} \\
\quad=0.2098+0.0074(47.2) \\
=0.5590
\end{array} \\
& \text { Where } \mathrm{C} \text { is coefficient. }
\end{aligned}
$$

\section{Design of the drainage channels}

Properly designed open ditches provide adequate drainage which provide sufficient capacity to carry the design flow which depend on the degree of protection required, water surface elevation low enough to drain the land, side slope limited in such a way that banks will neither cave in nor slide and velocity of flow such that neither serious scouring nor silting of any considerable extent will occur. The recommended side slope for clay loam soil is $1: 1.5$, Channel bed slope is $0.2 \%$, Drainage coefficient is $3.2 \mathrm{~cm} /$ day because the most of the problematic area (about 90\%) is paddy area and Velocity of flow is taken as $0.90 \mathrm{~m} / \mathrm{s}$.

On the basis of drainage requirement of study area, different types of drainage channels are designed i.e. 2 main drain for the total area, 6 sub main drain for collecting the excess water as mention in figure 7 . Their parameters for channels are $\mathrm{s}=0.2 \%, \mathrm{~V}=0.90 \mathrm{~m} / \mathrm{s}$, Side slope $=1: 1.5$ are given in table 1 .

\section{Results and Discussion}

Daily rainfall data from 2005 to 2014 were analyzed to find out maximum one, two, three, four and five consecutive days rainfall at different recurrence interval. In order to estimate drainage coefficient for surface drainage, 24 hours rainfall is required (USDA Manual) at five years recurrence interval, 24 hours rainfall for the study area is $230 \mathrm{~mm}$. 
Table.1 Cross Section of drains of various capabilities

\begin{tabular}{|c|c|c|c|c|c|c|}
\hline Plot No. & $\mathbf{A}$ & $\mathbf{Q}$ & DA & D & B & $\mathbf{T}$ \\
\hline 1 & 3.96 & 0.0691 & 0.0768 & 0.19 & 0.11 & 0.69 \\
\hline 2 & 3.29 & 0.0325 & 0.0709 & 0.18 & 0.11 & 0.66 \\
\hline 3 & 4.01 & 0.0383 & 0.0426 & 0.14 & 0.08 & 0.51 \\
\hline 4 & 1.89 & 0.0205 & 0.0227 & 0.1 & 0.06 & 0.37 \\
\hline 5 & 1.88 & 0.0204 & 0.0226 & 0.1 & 0.06 & 0.37 \\
\hline 6 & 1.95 & 0.021 & 0.0233 & 0.11 & 0.06 & 0.38 \\
\hline 7 & 1.98 & 0.0213 & 0.0236 & 0.11 & 0.06 & 0.38 \\
\hline 8 & 0.54 & 0.0131 & 0.0146 & 0.08 & 0.05 & 0.3 \\
\hline 9 & 2.16 & 0.0229 & 0.0254 & 0.11 & 0.07 & 0.4 \\
\hline 10 & 4.26 & 0.0735 & 0.0816 & 0.19 & 0.12 & 0.71 \\
\hline 11 & 4.00 & 0.0382 & 0.0425 & 0.14 & 0.08 & 0.51 \\
\hline 12 & 4.00 & 0.0382 & 0.0425 & 0.14 & 0.08 & 0.51 \\
\hline 13 & 4.00 & 0.0382 & 0.0425 & 0.14 & 0.08 & 0.51 \\
\hline 14 & 2.00 & 0.0215 & 0.0238 & 0.11 & 0.06 & 0.38 \\
\hline 15 & 2.00 & 0.0391 & 0.0435 & 0.14 & 0.09 & 0.52 \\
\hline 16 & 2.12 & 0.0225 & 0.025 & 0.11 & 0.07 & 0.39 \\
\hline 17 & 2.24 & 0.0236 & 0.0262 & 0.11 & 0.07 & 0.4 \\
\hline 18 & 3.07 & 0.0307 & 0.034 & 0.13 & 0.08 & 0.46 \\
\hline 19 & 1.4 & 0.0159 & 0.0177 & 0.09 & 0.05 & 0.33 \\
\hline 20 & 4.3 & 0.0406 & 0.0451 & 0.15 & 0.09 & 0.53 \\
\hline 21 & 4.31 & $0 . .041$ & 0.0452 & 0.15 & 0.09 & 0.53 \\
\hline 22 & 3.96 & 0.0379 & 0.0421 & 0.14 & 0.08 & 0.51 \\
\hline 23 & 4.17 & 0.0396 & 0.0439 & 0.14 & 0.09 & 0.52 \\
\hline 24 & 4 & 0.0382 & 00425 & 0.14 & 0.08 & 051 \\
\hline \multirow[t]{2}{*}{25} & 4 & 0.0382 & 0.0425 & 0.14 & 0.08 & 0.51 \\
\hline & \multicolumn{5}{|c|}{ SUB MAIN } & \\
\hline $1,2,3$ & 11.26 & 0.0906 & 0.1006 & 0.22 & 0.13 & 0.79 \\
\hline $4,5,6,7,8,9$ & 10.4 & 0.0848 & 0.0942 & 0.21 & 0.13 & 0.76 \\
\hline $10,11,12$ & 12.26 & 0.0972 & 0.1080 & 0.23 & 0.14 & 0.82 \\
\hline $13,14,15,16,17$ & 12.36 & 0.0979 & 0.1088 & 0.23 & 0.14 & 0.82 \\
\hline $18,19,20,21$ & 13.08 & 0.1026 & 0.1140 & 0.23 & 0.14 & $0 . .84$ \\
\hline \multirow[t]{2}{*}{$22,23,24,25$} & 16.13 & 0.1222 & 0.1358 & 0.25 & 0.15 & 0.92 \\
\hline & & \multicolumn{2}{|c|}{ MAIN DRAIN } & & & \\
\hline $1,2,3,10,11,12,18,19,20,21$ & 36.6 & 0.2419 & 02688 & 0.36 & 0.21 & 1.29 \\
\hline $\begin{array}{l}4,5,6,7,8,9 \\
, 13,14,15,16,17,22,23,24,25\end{array}$ & 38.89 & 0.2545 & 0.2827 & 0.37 & 0.22 & 1.32 \\
\hline
\end{tabular}




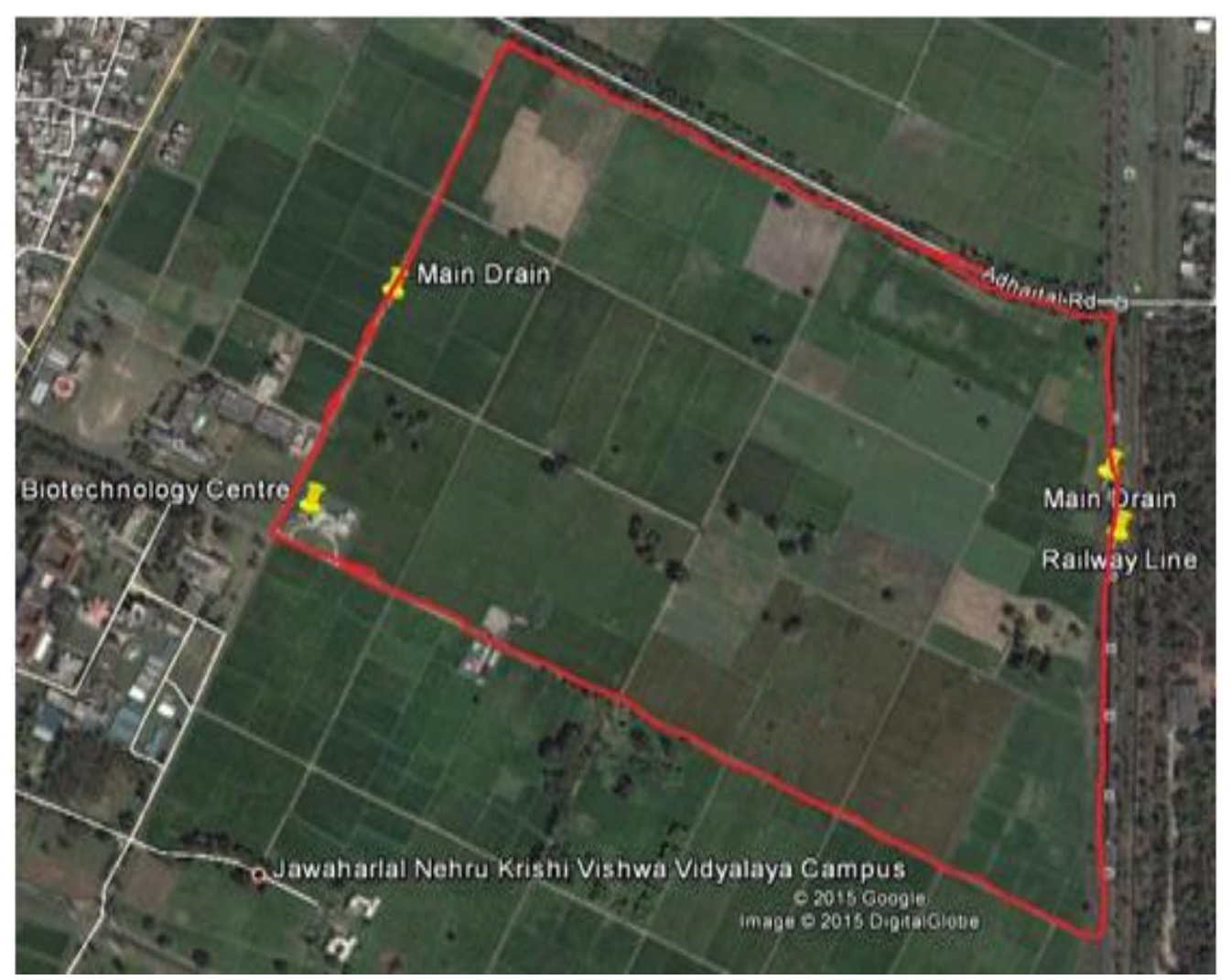

Figure.1 Study Area situated in in the premises of Jawaharlal Nehru Agricultural University (JNKVV), Jabalpur, Madhya Pradesh, India

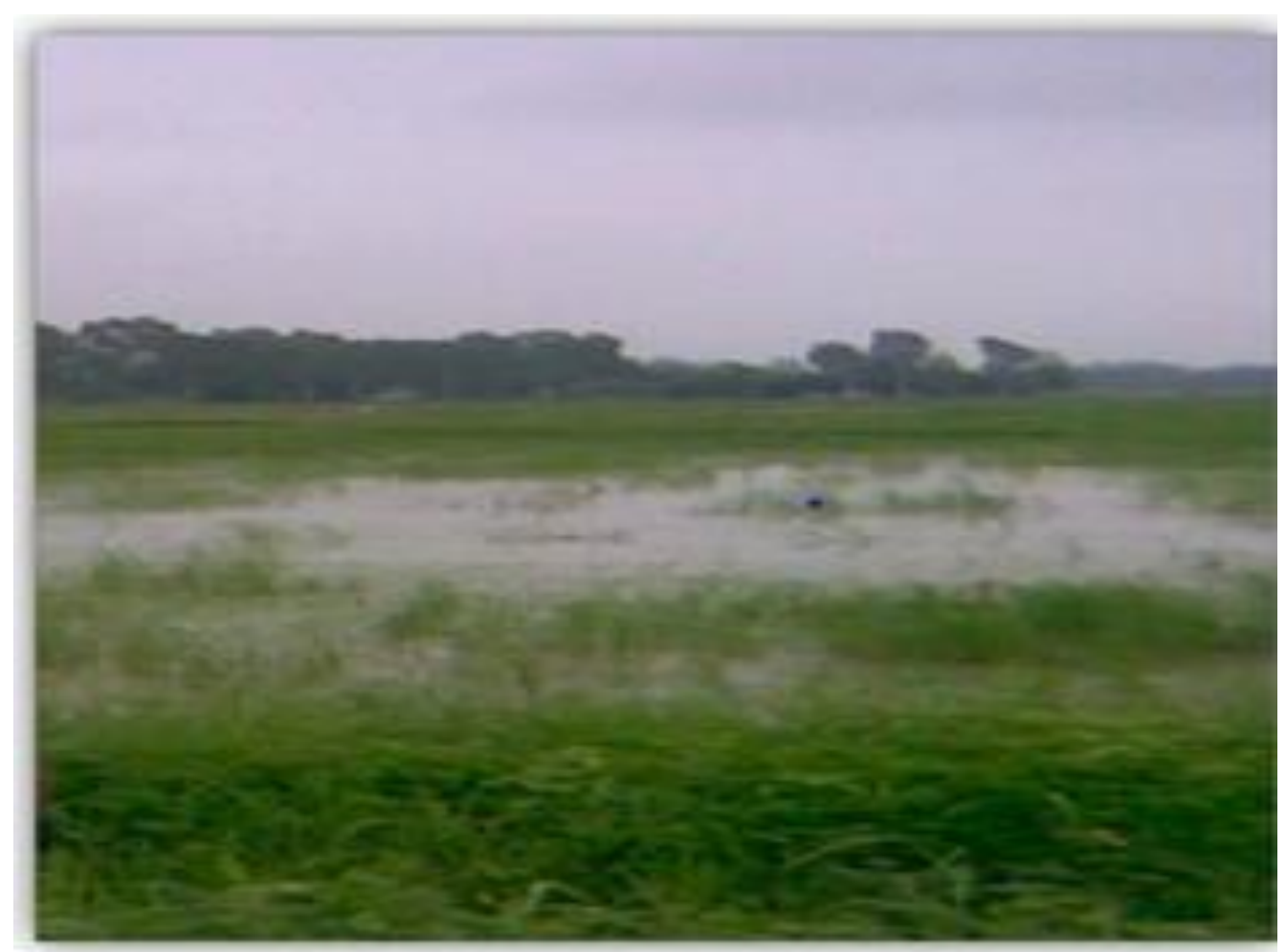

Figure.2 Waterlogging Condition of Field during rainy season 

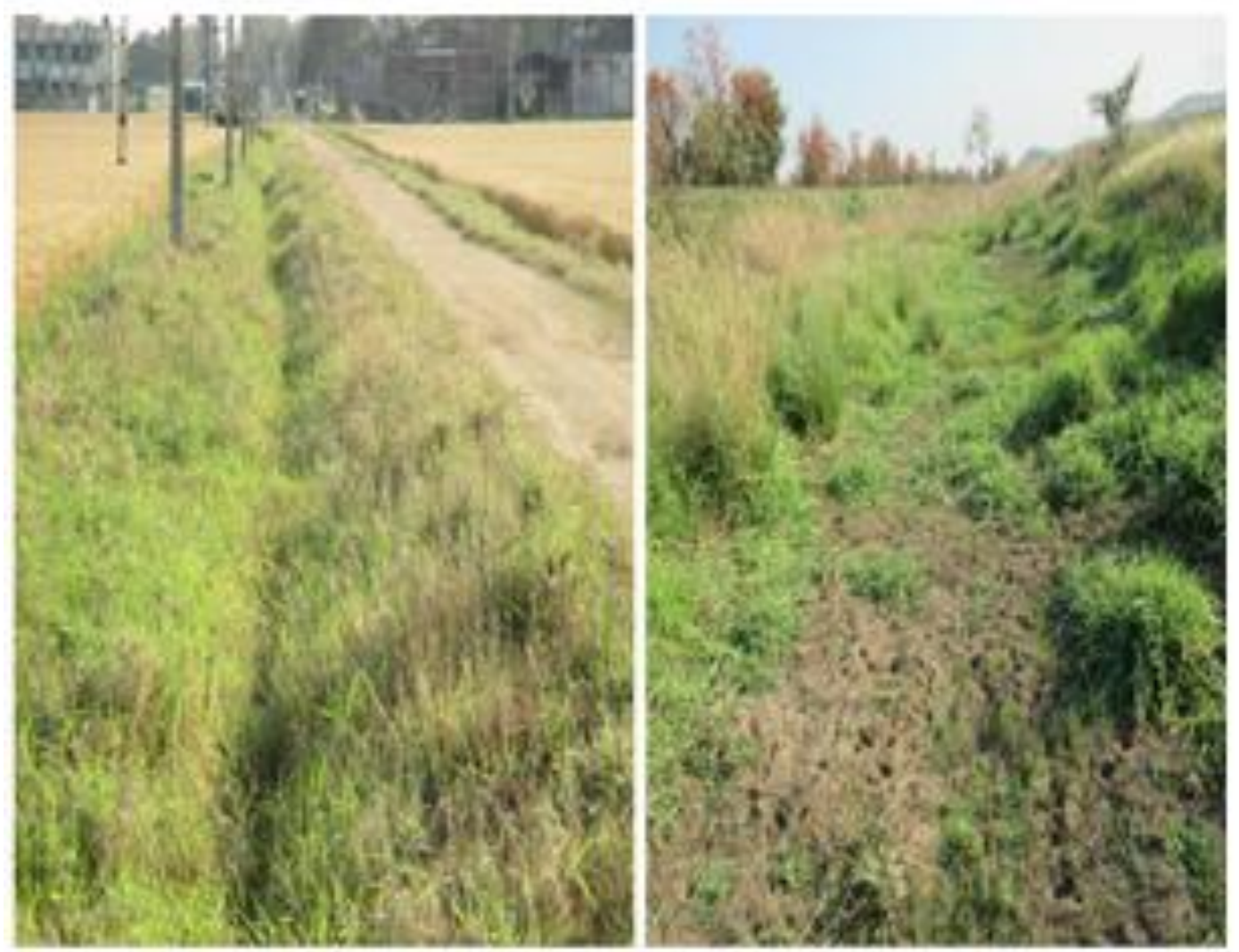

Figure.3 Drainage Line Condition of Area

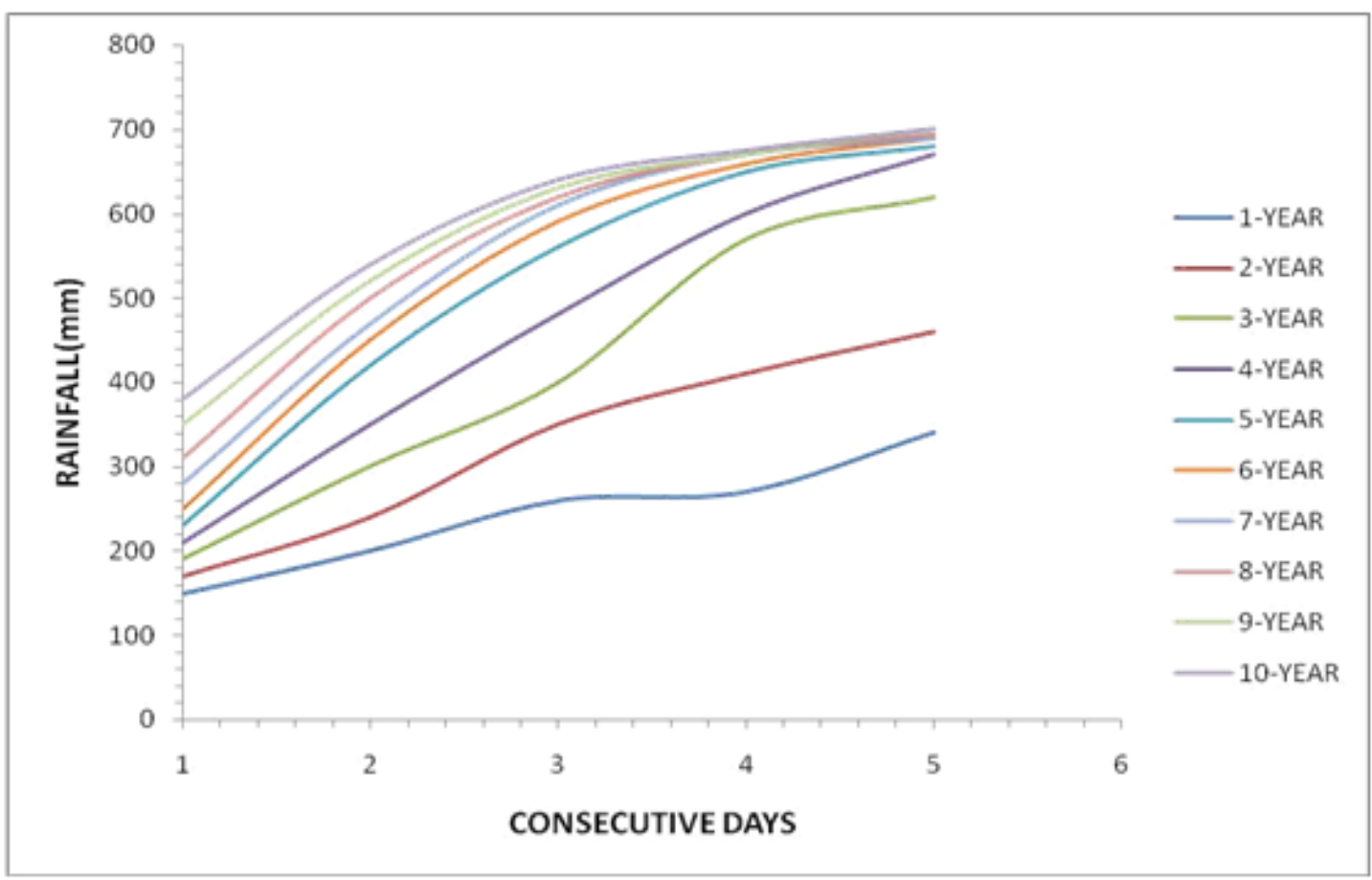

Figure.4 Depths, Duration and Frequency Relationship of Jabalpur 

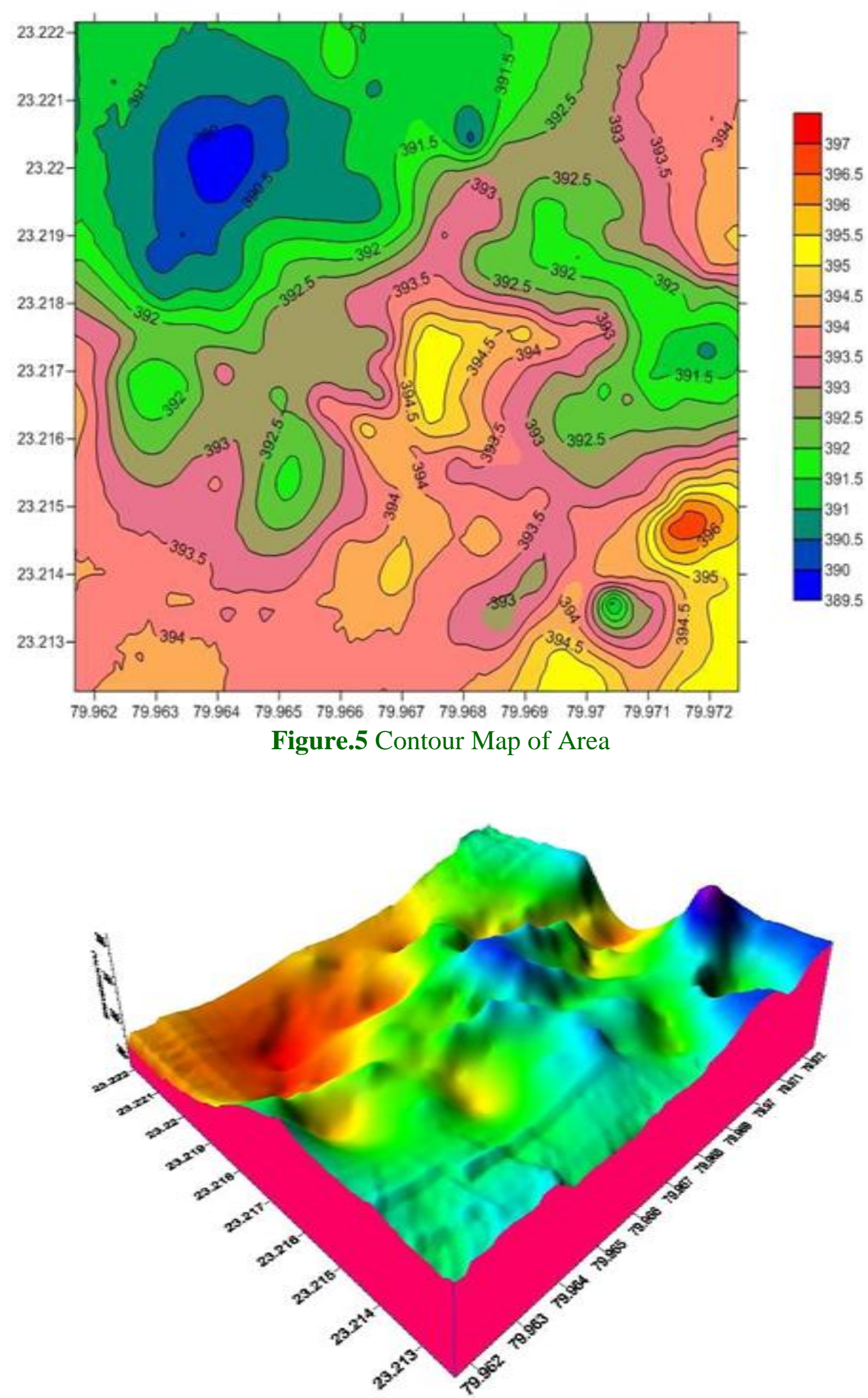

Figure.6 Three Dimensional Surface Map of Area 


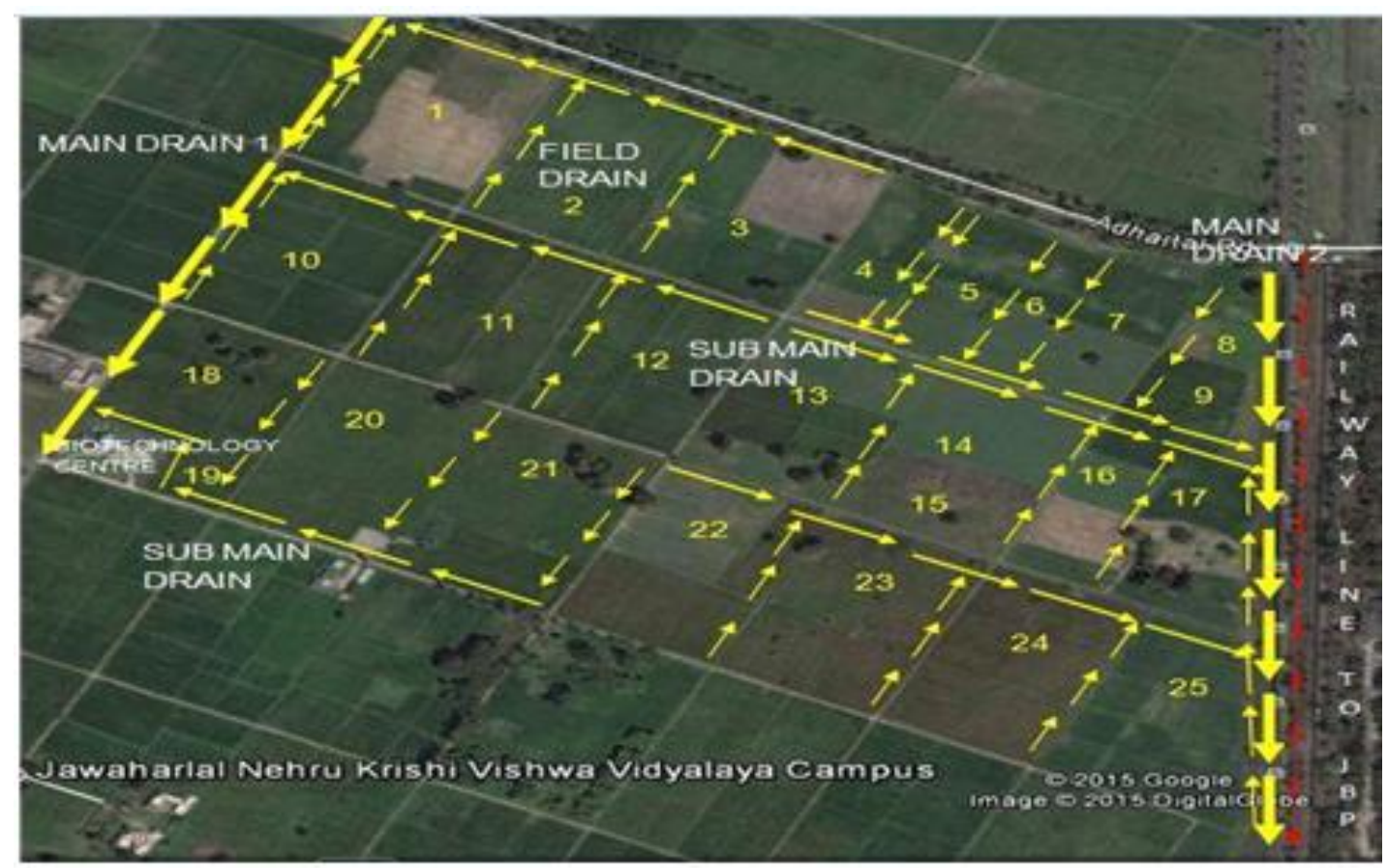

Figure.7 Layout of Surface Drainage System of JNKVV Farm

From the USDA textural classification, according to the percentage of sand, silt and clay found in the samples the surface texture of major area is clay loam. Analysis shows that the clay contain of the soil ranges from 29.3 to 29.8 percent, silt 31.1 to 33.5 percent and sand 37.2 to 39.1 percent and hence soils of the study area are classified as clay loam soils. The mean constant infiltration rate of the soil of the problematic area is determined as $0.55 \mathrm{~cm} / \mathrm{hr}$.

On analyzing 3-D surface map of study area, it was found that various places were impounded of water due to which water logging conditions were created, that lowers down the yield of paddy in that area. The design of surface drainage consists of two stages. The first stage is referred as the hydrological design for estimating or establishing the design drainage coefficient and the second stage is referred as the hydraulic design for facilitating the drainage. Based on previous five days rainfall total (> $53 \mathrm{~mm}$ ), the problematic area comes under the class AMC III.
The infiltration rate of the soil is low (2.5 $12.5 \mathrm{~mm} / \mathrm{h}$ ) hence the soil of problematic area comes under the hydrologic soil Group C. Relation b/w Ia vs. $\mathrm{S}$ for these condition is given as $\mathrm{Ia}=0.1 \mathrm{~S}$.

The total study area was 75.5 ha which had cropped land about 73.5 ha under straight cultivation and the cover condition was good, forestry land about 2.0 ha in poor coverage and Open area (Pasture) about 0.54 ha. Drainage coefficient for non-paddy area and paddy area is 1.019 and 0.559 . On the basis of drainage requirement of study area, different types of drainage channels are designed i.e. 2 main drains for the total area, 6 sub main drain for collecting the excess water. Their parameters for channels are $\mathrm{s}=0.2 \%, \mathrm{~V}=$ $0.90 \mathrm{~m} / \mathrm{s}$, Side slope $=1: 1.5$.

It has been observed that during monsoon season water logging problem occurs in most of the parts of the JNKVV Farm due to almost plain topography of land and poor conditions of drainage lines exist there. Therefore it is felt that there is need of properly designed 
surface drainage system to avoid further water logging in the area. The study has been under taken to investigate the drainage problems and design a proper drainage system for the problematic area. Contour map of problematic area has been prepared to find the existing slope, direction of the slope and outlets.

Rainfall data of ten years (2005 - 2014) have been analyzed to determine expected rainfall at different durations at one to ten years recurrence interval. Infiltration characteristics of the soil at three locations of the problematic area have been determined using double cylinder infiltrometer.

Design of agricultural drainage system consists of mainly two aspects i.e. hydrologic design and hydraulic design. Using soil characteristics, rainfall data, land use and land cover, drainage coefficient is computed with the help of HSC Curve Number method and used in drainage design.

A plan for surface drainage for the problematic area has been prepared. Layouts of laterals and main drains have been proposed and their dimensions are also computed.

On the basis of study carried out, following conclusions can be drawn -

There is water logging problem in study area which should be solved by properly designed surface drainage system. The study area has clay loam soil with low infiltration rate and nearly flat topography.

Since $90 \%$ area is under paddy crop, surface drainage system should be planned on the basis of drainage coefficient of paddy area.

For the study area, 6 sub main and 2 main drains are designed to overcome surface drainage problem of study area.

\section{References}

Agnihotri B. 1988. Drainage characteristics and reclamation of saline heavy clay soils, M.Tech. Thesis, College of Agril.Engg. JNKVV, Jabalpur.

Babu R. Ravi et al., 2006. Probability analysis of rainfall of Bankura for the design of soil and water conservation structures, "Journal of agricultural engineering”. 43.1 :pp- 2229.

Battu KR. 2001. Investigation on impact of rainfall distribution on runoff estimation using SCS Curve Number method. Unpublished M.Sc. Thesis, submitted to the Post Graduate school of IARI.

Dabral, PP and Baithuri, Neelakshi. 2007. Determination Of Surface Drainage Coefficient Through Rainfall Analysis For North Lakhmipur (Assam), Journal of Soil and Water Conservation, Vol.7, No.1,pp 38-42

Dabral, PP and Baithuri, Neelakshi. 2008. Determination Of Surface Drainage Coefficient Through Rainfall Analysis For North Lakhmipur (Assam), Journal of Soil and Water Conservation, Vol.7, No.1,pp $38-42$

Dass Bharati and A.K. Rai.2012 'Soil Electrical Conductivity - a Tool for Precision Farming' Journal of the Instrument Society of India, Vol 42(1) 21-22.

Datta, KK, Joshi ,PK, Singh O.P. and Rao KVGK. 1992. Evaluation of on-fann benefits of subsurface drainage for salinity control in the Trans Gangetic region of India. In: Proceedings of the 5th International Drainage Workshop, Lahore, Pakistan, Vol. III.

Jhariya P. 2012. Planning and design of surface drainage system of JNKVV farm, An unpublished M.Tech thesis, College of Agricultural Engineering, JNKVV Jabalpur

Kumar A.1987. Frequency analysis of rainfall data, a paper presented in $23^{\text {rd }}$ annual convention of ISAE held at Jabalpur, paper no.SWE -87-044.

Luo, W., Jia, Z. H., Fang, S. X., Wang, N., Liu, J., Wang, L., ... \& Zhang, Y. (2008). Outflow reduction and salt and nitrogen dynamics at controlled drainage in the YinNan Irrigation 
District, China. agricultural water management, 95(7), 809-816.

Michael ,A M and Ojha T P. 1966. principles of agricultural engineering, vol II, Ajanta Printers, Jain Brothers, Ratanada Road, Jodhpur.pp 300 -306.

MichealAM. 1978. Irrigation Theory and Pravtices, Vikas Publishing House Pvt. Ltd.5, Ansari Road, New Delhi.pp465-469.

Mohammad V. 2014. Drainage, Water logging and Salinity, Vol. 60, No. 12, 1625- 1640.

Ojha TP and Micheal AM.1978 .Principles of Agril.Engg.vol.II, Jain Brothers, East Park Road, Karol Bagh, New Delhi, pp.221-227.

Olver F W J. 1965. Bessel functions of integer order In: Milton Abramowitz and Irene A.Stegun (Editors), Handbook of Mathematical Functions, Dover Publications, Inc.,New York, 355-433.

Panda RK and Rajput T B S.. 2003. An Economic Drainage System Design for Coastal Paddy Areas of Orissa, Indian Journal of Soil Conservation, Vol .31 (1).pp 66-73.

Panda RK. 1999. Estimating the Extent of Surface Drainage Congestion by Manning's Roughness Coefficient Approach, Indian Journal of Soil Conservation, Vol.27(3).pp 198-201.

Patle GT, Wadtkar SB. and Hiww SS. 2005.Determination of Surface drainage coefficient through rainfall analysis. Journal of Agricultural Engineering, Vol. 42(1): 5357.

Philip JR. 1957. The theory of infiltration -1 The infiltration equation. Soil Science 83, pp $345-357$.

Rao, K V G K. 1985. Rainfall analysis for surface drainage design in rain fed low land rice fields, Journal of Agricultural Engineering,
Vol. 22 No. 3

Rusia DK. 1987. Drainage investigations in the command of Kunwarpur minor of Bargi Irrigation Project. An unpublished M.Tech.Thesis, College of Agril.Engg. JNKVV, Jabalpur.

Sarangi A. and Madramo C.A. 2003. Use of Misbach's Non-Darcy Equation in the Drainage Coefficient Through Rainfall Analysis, Journal of Agricultural Engineering, Vol. 42(1): 53-57

Schut, Bart, Thatte CP. and Labhestkar VK. 2005. Irrigation and Drainage: Main Contributors to Global Food Production, Journal of Irrigation and Drainage, Vol.54.pp 263 278.

Sharma RK., Kushwaha SS. and Yadav RD. 1997. Evaluating agricultural land drainage need in soils of Tawa command. Agricultural Engineering Today, $21(1-4): 16-24$.

Shekhawat, R. S. (2007). Economic analysis of sub-surface drainage under Indira Gandhi NaharPriyojna command area-A case study. Agricultural Economics Researh Review, 20(2), 361-374.

Smedema L.K. and Rycroft D.W.. (1988). Land drainage: Planning and design of agricultural drainage system, B.T. Batsford, London.

Welderufael, W. A., Le Roux, P. A. L., \& Hensley, M. (2009). Quantifying rainfallrunoff relationships on the Melkassa Hypo Calcic Regosolecotope in Ethiopia. Water SA, 35(5).

Welderufael, W. A., Le Roux, P. A. L., \& Hensley, M. (2009). Quantifying rainfallrunoff relationships on the Melkassa Hypo Calcic Regosol ecotope in Ethiopia. Water SA, 35(5).

\section{How to cite this article:}

Mukesh K. Seetpal, R. K. Patel, Bharti Dass and Sharad Patel. 2020. Planning and Design of Surface Drainage System of an Agricultural Farmland using HCS Curve Number Method with Most Economical Section. Int.J.Curr.Microbiol.App.Sci. 9(05): 1210-1222. doi: https://doi.org/10.20546/ijcmas.2020.905.135 